\title{
Cannabidiol as a Potential Treatment for Anxiety Disorders
}

\author{
Esther M. Blessing ${ }^{1}$ - Maria M. Steenkamp ${ }^{1}$ - Jorge Manzanares ${ }^{1,2}$. \\ Charles R. Marmar ${ }^{1}$
}

Published online: 4 September 2015

(C) The American Society for Experimental NeuroTherapeutics, Inc. 2015

\begin{abstract}
Cannabidiol (CBD), a Cannabis sativa constituent, is a pharmacologically broad-spectrum drug that in recent years has drawn increasing interest as a treatment for a range of neuropsychiatric disorders. The purpose of the current review is to determine CBD's potential as a treatment for anxiety-related disorders, by assessing evidence from preclinical, human experimental, clinical, and epidemiological studies. We found that existing preclinical evidence strongly supports $\mathrm{CBD}$ as a treatment for generalized anxiety disorder, panic disorder, social anxiety disorder, obsessive-compulsive disorder, and post-traumatic stress disorder when administered acutely; however, few studies have investigated chronic CBD dosing. Likewise, evidence from human studies supports an anxiolytic role of $\mathrm{CBD}$, but is currently limited to acute dosing, also with few studies in clinical populations. Overall, current evidence indicates CBD has considerable potential as a treatment for multiple anxiety disorders, with need for further study of chronic and therapeutic effects in relevant clinical populations.
\end{abstract}

Keywords Cannabidiol · Endocannabinoids · Anxiety · Generalized anxiety disorder $\cdot$ Post-traumatic stress disorder

Esther M. Blessing

esther.blessing@nyumc.org

New York University School of Medicine, New York, NY, USA

2 Instituto de Neurociencias de Alicante, Universidad Miguel Hernández and Consejo Superior de Investigaciones Científicas, Alicante, Spain

\section{Introduction}

Fear and anxiety are adaptive responses essential to coping with threats to survival. Yet excessive or persistent fear may be maladaptive, leading to disability. Symptoms arising from excessive fear and anxiety occur in a number of neuropsychiatric disorders, including generalized anxiety disorder (GAD), panic disorder (PD), post-traumatic stress disorder (PTSD), social anxiety disorder (SAD), and obsessive-compulsive disorder (OCD). Notably, PTSD and OCD are no longer classified as anxiety disorders in the recent revision of the Diagnostic and Statistical Manual of Mental Disorders-5; however, excessive anxiety is central to the symptomatology of both disorders. These anxiety-related disorders are associated with a diminished sense of well-being, elevated rates of unemployment and relationship breakdown, and elevated suicide risk [1-3]. Together, they have a lifetime prevalence in the USA of $29 \%$ [4], the highest of any mental disorder, and constitute an immense social and economic burden $[5,6]$.

Currently available pharmacological treatments include serotonin reuptake inhibitors, serotonin-norepinephrine reuptake inhibitors, benzodiazepines, monoamine oxidase inhibitors, tricyclic antidepressant drugs, and partial 5-hydroxytryptamine (5HT) $)_{1 \mathrm{~A}}$ receptor agonists. Anticonvulsants and atypical antipsychotics are also used to treat PTSD. These medications are associated with limited response rates and residual symptoms, particularly in PTSD, and adverse effects may also limit tolerability and adherence [7-10]. The substantial burden of anxiety-related disorders and the limitations of current treatments place a high priority on developing novel pharmaceutical treatments.

Cannabidiol (CBD) is a phytocannabinoid constituent of Cannabis sativa that lacks the psychoactive effects of $\Delta^{9-}$ tetrahydrocannabinol (THC). CBD has broad therapeutic properties across a range of neuropsychiatric disorders, stemming from diverse central nervous system actions $[11,12]$. In recent 
years, CBD has attracted increasing interest as a potential anxiolytic treatment [13-15]. The purpose of this review is to assess evidence from current preclinical, clinical, and epidemiological studies pertaining to the potential risks and benefits of $\mathrm{CBD}$ as a treatment for anxiety disorders.

\section{Methods}

A search of MEDLINE (PubMed), PsycINFO, Web of Science Scopus, and the Cochrane Library databases was conducted for English-language papers published up to 1 January 2015, using the search terms "cannabidiol" and "anxiety" or "fear" or "stress" or "anxiety disorder" or "generalized anxiety disorder" or "social anxiety disorder" or "social phobia" or "post-traumatic stress disorder" or "panic disorder" or "obsessive compulsive disorder". In total, 49 primary preclinical, clinical, or epidemiological studies were included. Neuroimaging studies that documented results from anxiety-related tasks, or resting neural activity, were included. Epidemiological or clinical studies that assessed CBD's effects on anxiety symptoms, or the potential protective effects of CBD on anxiety symptoms induced by cannabis use (where the CBD content of cannabis is inferred via a higher CBD:THC ratio), were included.

\section{CBD Pharmacology Relevant to Anxiety}

\section{General Pharmacology and Therapeutic Profile}

Cannabis sativa, a species of the Cannabis genus of flowering plants, is one of the most frequently used illicit recreational substances in Western culture. The 2 major phyto- cannabinoid constituents with central nervous system activity are THC, responsible for the euphoric and mind-altering effects, and CBD, which lacks these psychoactive effects. Preclinical and clinical studies show CBD possesses a wide range of therapeutic properties, including antipsychotic, analgesic, neuroprotective, anticonvulsant, antiemetic, antioxidant, anti-inflammatory, antiarthritic, and antineoplastic properties (see [11, 12, 16-19] for reviews). A review of potential side effects in humans found that $\mathrm{CBD}$ was well tolerated across a wide dose range, up to $1500 \mathrm{mg} /$ day (orally), with no reported psychomotor slowing, negative mood effects, or vital sign abnormalities noted [20].

CBD has a broad pharmacological profile, including interactions with several receptors known to regulate fear and anxiety-related behaviors, specifically the cannabinoid type 1 receptor $\left(\mathrm{CB}_{1} \mathrm{R}\right)$, the serotonin $5-\mathrm{HT}_{1 \mathrm{~A}}$ receptor, and the transient receptor potential (TRP) vanilloid type 1 (TRPV1) receptor $[11,12,19,21]$. In addition, CBD may also regulate, directly or indirectly, the peroxisome proliferator-activated receptor- $\gamma$, the orphan G-protein-coupled receptor 55, the equilibrative nucleoside transporter, the adenosine transporter, additional TRP channels, and glycine receptors [11, 12, 19, 21]. In the current review of primary studies, the following receptor-specific actions were found to have been investigated as potential mediators of CBD's anxiolytic action: $\mathrm{CB}_{1} \mathrm{R}$, TRPV1 receptors, and 5- $\mathrm{HT}_{1 \mathrm{~A}}$ receptors. Pharmacology relevant to these actions is detailed below.

\section{The Endocannabinoid System}

Following cloning of the endogenous receptor for THC, namely the $\mathrm{CB}_{1} \mathrm{R}$, endogenous $\mathrm{CB}_{1} \mathrm{R}$ ligands, or "endocannabinoids" (eCBs) were discovered, namely anandamide (AEA) and 2-arachidonoylglycerol (reviewed in [22]). The $\mathrm{CB}_{1} \mathrm{R}$ is an inhibitory $\mathrm{G}_{\mathrm{i} / \mathrm{o}}$ protein-coupled receptor that is mainly localized to nerve terminals, and is expressed on both $\gamma$-aminobutryic acid-ergic and glutamatergic neurons. eCBs are fatty acid derivatives that are synthesized on demand in response to neuronal depolarization and $\mathrm{Ca}^{2+}$ influx, via cleavage of membrane phospholipids. The primary mechanism by which eCBs regulate synaptic function is retrograde signaling, wherein eCBs produced by depolarization of the postsynaptic neuron activate presynaptic $\mathrm{CB}_{1} \mathrm{Rs}$, leading to inhibition of neurotransmitter release [23]. The "eCB system" includes AEA and 2-arachidonoylglycerol; their respective degradative enzymes fatty acid amide hydroxylase (FAAH) and monoacylglycerol lipase; the $\mathrm{CB}_{1} \mathrm{R}$ and related $\mathrm{CB}_{2}$ receptor (the latter expressed mainly in the periphery); as well as several other receptors activated by eCBs, including the TRPV1 receptor, peroxisome proliferator-activated receptor- $\gamma$, and G protein-coupled 55 receptor, which functionally interact with $\mathrm{CB}_{1} \mathrm{R}$ signaling (reviewed in $[21,24]$ ). Interactions with the TRPV1 receptor, in particular, appear to be critical in regulating the extent to which eCB release leads to inhibition or facilitation of presynaptic neurotransmitter release [25]. The TRPV1 receptor is a postsynaptic cation channel that underlies sensation of noxious heat in the periphery, with capsacin (hot chili) as an exogenous ligand. TRPV1 receptors are also expressed in the brain, including the amygdala, periaqueductal grey, hippocampus, and other areas [26, 27].

The eCB system regulates diverse physiological functions, including caloric energy balance and immune function [28]. The eCB system is also integral to regulation of emotional behavior, being essential to forms of synaptic plasticity that determine learning and response to emotionally salient, particularly highly aversive events $[29,30]$. Activation of $\mathrm{CB}_{1} \mathrm{Rs}$ produces anxiolytic effects in various models of unconditioned fear, relevant to multiple anxiety disorder symptom domains (reviewed in [30-33]). Regarding conditioned fear, the effect of $\mathrm{CB}_{1} \mathrm{R}$ activation is complex: $\mathrm{CB}_{1} \mathrm{R}$ activation may enhance or reduce fear expression, depending on brain locus and the eCB ligand [34]; however, $\mathrm{CB}_{1} \mathrm{R}$ activation potently enhances fear extinction [35], and can prevent fear reconsolidation. Genetic manipulations that impede 
$\mathrm{CB}_{1} \mathrm{R}$ activation are anxiogenic [35], and individuals with $\mathrm{eCB}$ system gene polymorphisms that reduce $\mathrm{eCB}$ tonefor example, FAAH gene polymorphisms - exhibit physiological, psychological, and neuroimaging features consistent with impaired fear regulation [36]. Reduction of AEA- $\mathrm{CB}_{1} \mathrm{R}$ signaling in the amygdala mediates the anxiogenic effects of corticotropin-releasing hormone [37], and $\mathrm{CB}_{1} \mathrm{R}$ activation is essential to negative feedback of the neuroendocrine stress response, and protects against the adverse effects of chronic stress [38, 39]. Finally, chronic stress impairs eCB signaling in the hippocampus and amygdala, leading to anxiety [40, 41], and people with PTSD show elevated $\mathrm{CB}_{1} \mathrm{R}$ availability and reduced peripheral AEA, suggestive of reduced eCB tone [42].

Accordingly, $\mathrm{CB}_{1} \mathrm{R}$ activation has been suggested as a target for anxiolytic drug development [15, 43, 44]. Proposed agents for enhancing $\mathrm{CB}_{1} \mathrm{R}$ activation include $\mathrm{THC}$, which is a potent and direct agonist; synthetic $\mathrm{CB}_{1} \mathrm{R}$ agonists; FAAH inhibitors and other agents that increase eCB availability, as well as nonpsychoactive cannabis phytocannabinoids, including CBD. While CBD has low affinity for the $\mathrm{CB}_{1} \mathrm{R}$, it functions as an indirect agonist, potentially via augmentation of $\mathrm{CB}_{1} \mathrm{R}$ constitutional activity, or via increasing AEA through FAAH inhibition (reviewed in [21]).

Several complexities of the eCB system may impact upon the potential of $\mathrm{CBD}$ and other $\mathrm{CB}_{1} \mathrm{R}$-activating agents to serve as anxiolytic drugs. First, $\mathrm{CB}_{1} \mathrm{R}$ agonists, including $\mathrm{THC}$ and AEA, have a biphasic effect: low doses are anxiolytic, but higher doses are ineffective or anxiogenic, in both preclinical models in and humans (reviewed in [33, 45]). This biphasic profile may stem from the capacity of $\mathrm{CB}_{1} \mathrm{R}$ agonists to also activate TRPV1 receptors when administered at a high, but not low dose, as demonstrated for AEA [46]. Activation of TRPV1 receptors is predominantly anxiogenic, and thus a critical balance of eCB levels, determining $\mathrm{CB} 1$ versus TRPV1 activation, is proposed to govern emotional behavior [27, 47]. CBD acts as a TRPV1 agonist at high concentrations, potentially by interfering with AEA inactivation [48]. In addition to dose-dependent activation of TRPV1 channels, the anxiogenic versus anxiolytic balance of $\mathrm{CB}_{1} \mathrm{R}$ agonists also depends on dynamic factors, including environmental stressors [33, 49].

\section{5-HT ${ }_{1 \mathrm{~A}}$ Receptors}

The 5-HT $\mathrm{H}_{1 \mathrm{~A}}$ receptor $\left(5-\mathrm{HT}_{1 \mathrm{~A}} \mathrm{R}\right)$ is an established anxiolytic target. Buspirone and other $5-\mathrm{HT}_{1 \mathrm{~A}} \mathrm{R}$ agonists are approved for the treatment of GAD, with fair response rates [50]. In preclinical studies, $5-\mathrm{HT}_{1 \mathrm{~A}} \mathrm{R}$ agonists are anxiolytic in animal models of general anxiety [51], prevent the adverse effects of stress [52], and enhance fear extinction [53]. Both pre- and postsynaptic $5-\mathrm{HT}_{1 \mathrm{~A}} \mathrm{Rs}$ are coupled to various members of the $\mathrm{G}_{\mathrm{i} / \mathrm{o}}$ protein family. They are expressed on serotonergic neurons in the raphe, where they exert autoinhibitory function, and various other brain areas involved in fear and anxiety [54, 55]. Mechanisms underlying the anxiolytic effects of $5-\mathrm{HT}_{1 \mathrm{~A}} \mathrm{R}$ activation are complex, varying between both brain region, and pre- versus postsynaptic locus, and are not fully established [56]. While in vitro studies suggest $\mathrm{CBD}$ acts as a direct $5-\mathrm{HT}_{1 \mathrm{~A}} \mathrm{R}$ agonist [57], in vivo studies are more consistent with $\mathrm{CBD}$ acting as an allosteric modulator, or facilitator of $5-\mathrm{HT}_{1 \mathrm{~A}}$ signaling [58].

\section{Preclinical Evaluations}

\section{Generalized Anxiety Models}

Relevant studies in animal models are summarized in chronological order in Table 1. CBD has been studied in a wide range of animal models of general anxiety, including the elevated plus maze (EPM), the Vogel-conflict test (VCT), and the elevated T maze (ETM). See Table 1 for the anxiolytic effect specific to each paradigm. Initial studies of CBD in these models showed conflicting results: high $(100 \mathrm{mg} / \mathrm{kg})$ doses were ineffective, while low $(10 \mathrm{mg} / \mathrm{kg})$ doses were anxiolytic $[59,60]$. When tested over a wide range of doses in further studies, the anxiolytic effects of CBD presented a bell-shaped dose-response curve, with anxiolytic effects observed at moderate but not higher doses $[61,90]$. All further studies of acute systemic CBD without prior stress showed anxiolytic effects or no effect [62, 65], the latter study involving intracerebroventricular rather than the intraperitoneal route. No anxiogenic effects of acute systemic CBD dosing in models of general anxiety have yet been reported. As yet, few studies have examined chronic dosing effects of CBD in models of generalized anxiety. Campos et al. [66] showed that in rat, CBD treatment for 21 days attenuated inhibitory avoidance acquisition [83]. Long et al. [69] showed that, in mouse, CBD produced moderate anxiolytic effects in some paradigms, with no effects in others.

Anxiolytic effects of CBD in models of generalized anxiety have been linked to specific receptor mechanisms and brain regions. The midbrain dorsal periaqueductal gray (DPAG) is integral to anxiety, orchestrating autonomic and behavioral responses to threat [91], and DPAG stimulation in humans produces feelings of intense distress and dread [92]. Microinjection of CBD into the DPAG produced anxiolytic effects in the EPM, VGC, and ETM that were partially mediated by activation of $5-\mathrm{HT}_{1 \mathrm{~A}} \mathrm{Rs}$ but not by $\mathrm{CB}_{1} \mathrm{Rs}[65,68]$. The bed nucleus of the stria terminalis (BNST) serves as a principal output structure of the amygdaloid complex to coordinate sustained fear responses, relevant to anxiety [93]. Anxiolytic effects of CBD in the EPM and VCT occurred upon microinjection into the BNST, where they depended on $5-\mathrm{HT}_{1 \mathrm{~A}} \mathrm{R}$ 


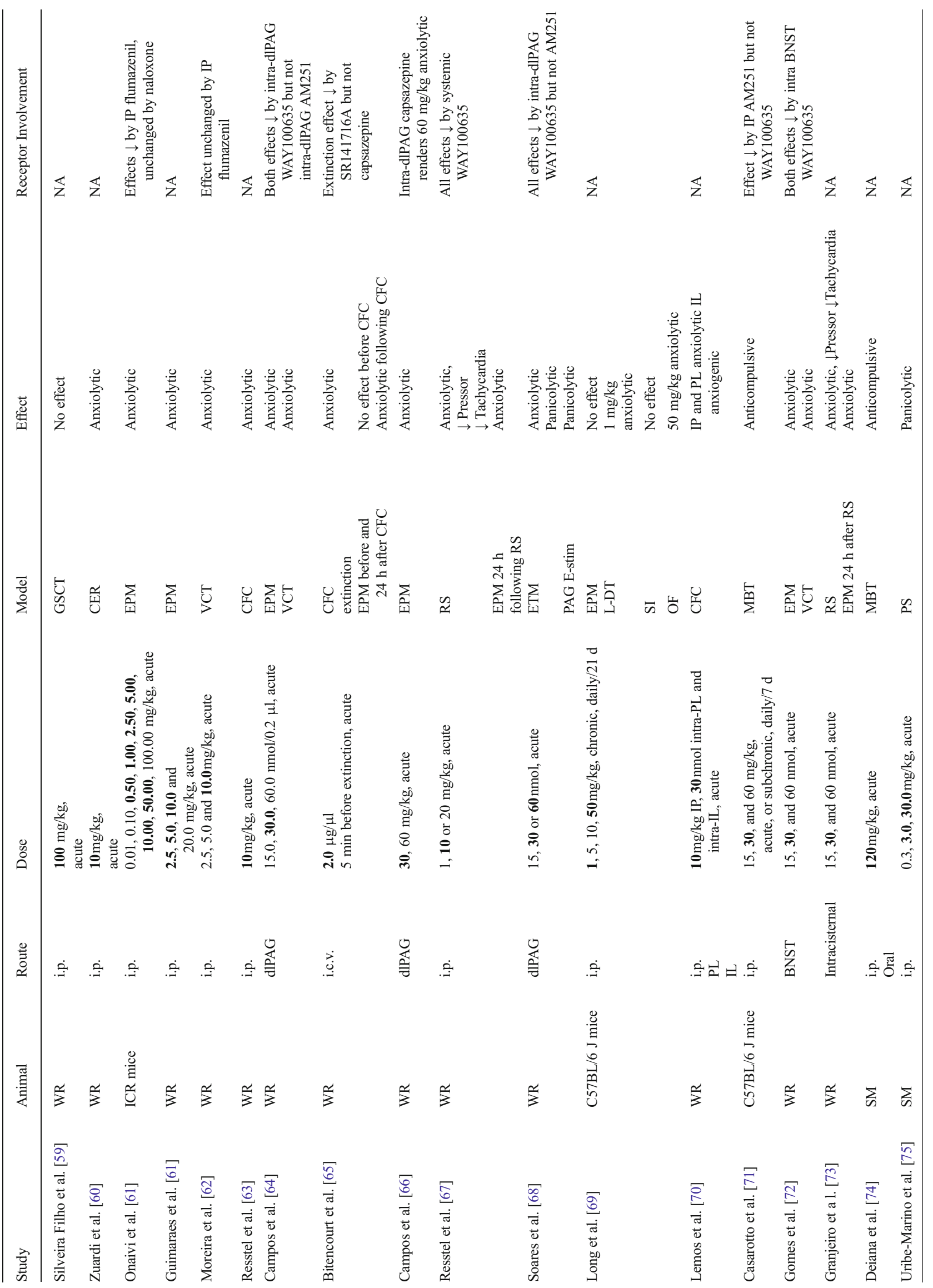




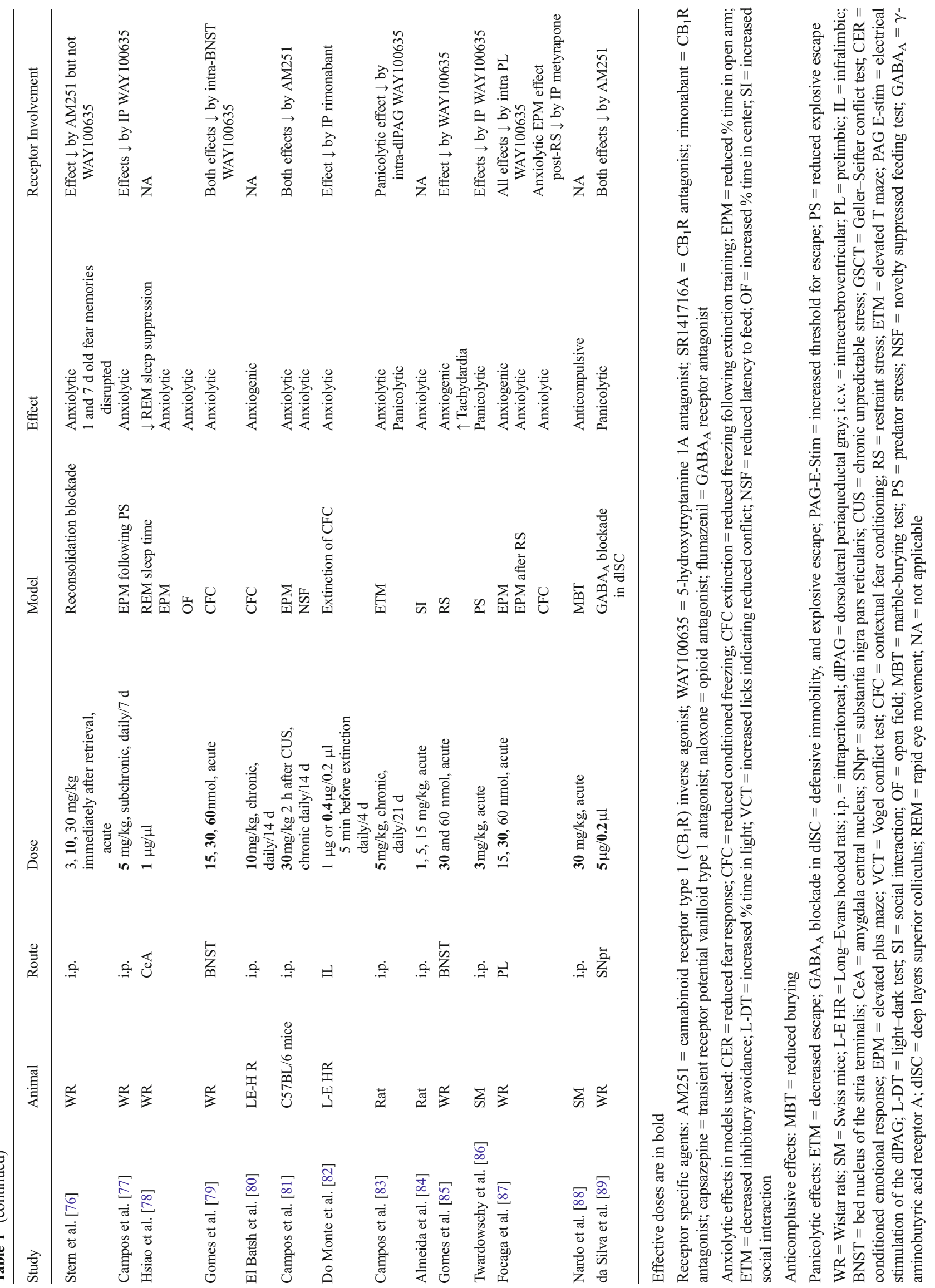


activation [79], and also upon microinjection into the central nucleus of the amygdala [78]. In the prelimbic cortex, which drives expression of fear responses via connections with the amygdala [94], CBD had more complex effects: in unstressed rats, CBD was anxiogenic in the EPM, partially via $5-\mathrm{HT}_{1 \mathrm{~A}} \mathrm{R}$ receptor activation; however, following acute restraint stress, CBD was anxiolytic [87]. Finally, the anxiolytic effects of systemic CBD partially depended on $\mathrm{GABA}_{\mathrm{A}}$ receptor activation in the EPM model but not in the VCT model [61, 62].

As noted, CBD has been found to have a bell-shaped response curve, with higher doses being ineffective. This may reflect activation of TRPV1 receptors at higher dose, as blockade of TRPV1 receptors in the DPAG rendered a previously ineffective high dose of CBD as anxiolytic in the EPM [66]. Given TRPV1 receptors have anxiogenic effects, this may indicate that at higher doses, CBD's interaction with TRPV1 receptors to some extent impedes anxiolytic actions, although was notably not sufficient to produce anxiogenic effects.

\section{Stress-induced Anxiety Models}

Stress is an important contributor to anxiety disorders, and traumatic stress exposure is essential to the development of PTSD. Systemically administered CBD reduced acute increases in heart rate and blood pressure induced by restraint stress, as well as the delayed $(24 \mathrm{~h})$ anxiogenic effects of stress in the EPM, partially by $5-\mathrm{HT}_{1 \mathrm{~A}} \mathrm{R}$ activation $[67,73]$. However intra-BNST microinjection of CBD augmented stressinduced heart rate increase, also partially via $5-\mathrm{HT}_{1 \mathrm{~A}} \mathrm{R}$ activation [85]. In a subchronic study, CBD administered daily $1 \mathrm{~h}$ after predator stress (a proposed model of PTSD) reduced the long-lasting anxiogenic effects of chronic predator stress, partially via $5-\mathrm{HT}_{1 \mathrm{~A}} \mathrm{R}$ activation [77]. In a chronic study, systemic CBD prevented increased anxiety produced by chronic unpredictable stress, in addition to increasing hippocampal $\mathrm{AEA}$; these anxiolytic effects depended upon $\mathrm{CB}_{1} \mathrm{R}$ activation and hippocampal neurogenesis, as demonstrated by genetic ablation techniques [81]. Prior stress also appears to modulate CBD's anxiogenic effects: microinjection of CBD into the prelimbic cortex of unstressed animals was anxiogenic in the EPM but following restraint stress was found to be anxiolytic [87]. Likewise, systemic CBD was anxiolytic in the EPM following but not prior to stress [65].

\section{PD and Compulsive Behavior Models}

CBD inhibited escape responses in the ETM and increased DPAG escape electrical threshold [68], both proposed models of panic attacks [95]. These effects partially depended on 5$\mathrm{HT}_{1 \mathrm{~A}} \mathrm{R}$ activation but were not affected by $\mathrm{CB}_{1} \mathrm{R}$ blockade. $\mathrm{CBD}$ was also panicolytic in the predator-prey model, which assesses explosive escape and defensive immobility in response to a boa constrictor snake, also partially via $5-\mathrm{HT}_{1 \mathrm{~A}} \mathrm{R}$ activation; however, more consistent with an anxiogenic effect, $\mathrm{CBD}$ was also noted to decrease time spent outside the burrow and increase defensive attention (not shown in Table 1) $[75,86]$. Finally, $C B D$, partially via $\mathrm{CB}_{1} \mathrm{Rs}$, decreased defensive immobility and explosive escape caused by bicuculline-induced neuronal activation in the superior colliculus [89]. Anticompulsive effects of CBD were investigated in marble-burying behavior, conceptualized to model OCD [96]. Acute systemic CBD reduced marble-burying behavior for up to 7 days, with no attenuation in effect up to high $(120 \mathrm{mg} / \mathrm{kg})$ doses, and effect shown to depend on $\mathrm{CB}_{1}$ Rs but not $5-\mathrm{HT}_{1 \mathrm{~A}} \mathrm{Rs}[71,74,88]$.

\section{Contextual Fear Conditioning, Fear Extinction, and Reconsolidation Blockade}

Several studies assessed CBD using contextual fear conditioning. Briefly, this paradigm involves pairing a neutral context, the conditioned stimulus (CS), with an aversive unconditioned stimulus (US), a mild foot shock. After repeated pairings, the subject learns that the CS predicts the US, and subsequent CS presentation elicits freezing and other physiological responses. Systemic administration of CBD prior to CS re-exposure reduced conditioned cardiovascular responses [63], an effect reproduced by microinjection of CBD into the BNST, and partially mediated by 5$\mathrm{HT}_{1 \mathrm{~A}} \mathrm{R}$ activation [79]. Similarly, CBD in the prelimbic cortex reduced conditioned freezing [70], an effect prevented by $5-\mathrm{HT}_{1 \mathrm{~A}} \mathrm{R}$ blockade [87]. By contrast, CBD microinjection in the infralimbic cortex enhanced conditioned freezing [70]. Finally, El Batsh et al. [80] reported that repeated CBD doses over 21 days, that is chronic as opposed to acute treatment, facilitated conditioned freezing. In this study, CBD was administered prior to conditioning rather than prior to re-exposure as in acute studies, thus further directly comparable studies are required.

CBD has also been shown to enhance extinction of contextually conditioned fear responses. Extinction training involves repeated CS exposure in the absence of the US, leading to the formation of a new memory that inhibits fear responses and a decline in freezing over subsequent training sessions. Systemic CBD administration immediately before training markedly enhanced extinction, and this effect depended on $\mathrm{CB}_{1} \mathrm{R}$ activation, without involvement of TRPV1 receptors [65]. Further studies showed $\mathrm{CB}_{1} \mathrm{Rs}$ in the infralimbic cortex may be involved in this effect [82].

CBD also blocked reconsolidation of aversive memories in rat [76]. Briefly, fear memories, when reactivated by re-exposure (retrieval), enter into a labile state in 
which the memory trace may either be reconsolidated or extinguished [97], and this process may be pharmacologically modulated to achieve reconsolidation blockade or extinction. When administered immediately following retrieval, CBD prevented freezing to the conditioned context upon further re-exposure, and no reinstatement or spontaneous recovery was observed over 3 weeks, consistent with reconsolidation blockade rather than extinction [76]. This effect depended on $\mathrm{CB}_{1} \mathrm{R}$ activation but not $5-\mathrm{HT}_{1 \mathrm{~A}} \mathrm{R}$ activation [76].

\section{Summary and Clinical Relevance}

Overall, existing preclinical evidence strongly supports the potential of $\mathrm{CBD}$ as a treatment for anxiety disorders. CBD exhibits a broad range of actions, relevant to multiple symptom domains, including anxiolytic, panicolytic, and anticompulsive actions, as well as a decrease in autonomic arousal, a decrease in conditioned fear expression, enhancement of fear extinction, reconsolidation blockade, and prevention of the long-term anxiogenic effects of stress. Activation of 5$\mathrm{HT}_{1 \mathrm{~A}} \mathrm{Rs}$ appears to mediate anxiolytic and panicolytic effects, in addition to reducing conditioned fear expression, although $\mathrm{CB}_{1} \mathrm{R}$ activation may play a limited role. By contrast, $\mathrm{CB}_{1} \mathrm{R}$ activation appears to mediate CBD's anticompulsive effects, enhancement of fear extinction, reconsolidation blockade, and capacity to prevent the long-term anxiogenic consequences of stress, with involvement of hippocampal neurogenesis.

While CBD predominantly has acute anxiolytic effects, some species discrepancies are apparent. In addition, effects may be contingent on prior stress and vary according to brain region. A notable contrast between $\mathrm{CBD}$ and other agents that target the eCB system, including $\mathrm{THC}$, direct $\mathrm{CB}_{1} \mathrm{R}$ agonists and $\mathrm{FAAH}$ inhibitors, is a lack of anxiogenic effects at a higher dose. Further receptor-specific studies may elucidate the receptor specific basis of this distinct dose response profile. Further studies are also required to establish the efficacy of CBD when administered in chronic dosing, as relatively few relevant studies exist, with mixed results, including both anxiolytic and anxiogenic outcomes.

Overall, preclinical evidence supports systemic CBD as an acute treatment of GAD, SAD, PD, OCD, and PTSD, and suggests that CBD has the advantage of not producing anxiogenic effects at higher dose, as distinct from other agents that enhance $\mathrm{CB}_{1} \mathrm{R}$ activation. In particular, results show potential for the treatment of multiple PTSD symptom domains, including reducing arousal and avoidance, preventing the long-term adverse effects of stress, as well as enhancing the extinction and blocking the reconsolidation of persistent fear memories.

\section{Human Experimental and Clinical Studies}

\section{Evidence from Acute Psychological Studies}

Relevant studies are summarized in Table 2. The anxiolytic effects of CBD in humans were first demonstrated in the context of reversing the anxiogenic effects of THC. CBD reduced THC-induced anxiety when administered simultaneously with this agent, but had no effect on baseline anxiety when administered alone [99, 100]. Further studies using higher doses supported a lack of anxiolytic effects at baseline [101, 107]. By contrast, CBD potently reduces experimentally induced anxiety or fear. CBD reduced anxiety associated with a simulated public speaking test in healthy subjects, and in subjects with $\mathrm{SAD}$, showing a comparable efficacy to ipsapirone (a 5$\mathrm{HT}_{1 \mathrm{~A}} \mathrm{R}$ agonist) or diazepam $[98,105]$. CBD also reduced the presumed anticipatory anxiety associated with undergoing a single-photon emission computed tomography (SPECT) imaging procedure, in both healthy and SAD subjects [102, 104]. Finally, CBD enhanced extinction of fear memories in healthy volunteers: specifically, inhaled CBD administered prior to or after extinction training in a contextual fear conditioning paradigm led to a trend-level enhancement in the reduction of skin conductance response during reinstatement, and a significant reduction in expectancy (of shock) ratings during reinstatement [106].

\section{Evidence from Neuroimaging Studies}

Relevant studies are summarized in Table 3. In a SPECT study of resting cerebral blood flow (rCBF) in normal subjects, $\mathrm{CBD}$ reduced $\mathrm{rCBF}$ in left medial temporal areas, including the amygdala and hippocampus, as well as the hypothalamus and left posterior cingulate gyrus, but increased $\mathrm{rCBF}$ in the left parahippocampal gyrus. These $\mathrm{rCBF}$ changes were not correlated with anxiolytic effects [102]. In a SPECT study, by the same authors, in patients with SAD, CBD reduced rCBF in overlapping, but distinct, limbic and paralimbic areas; again, with no correlations to anxiolytic effects [104].

In a series of placebo-controlled studies involving 15 healthy volunteers, Fusar-Poli et al. investigated the effects of CBD and THC on task-related blood-oxygen-level dependent functional magnetic resonance imaging activation, specifically the go/no-go and fearful faces tasks $[109,110]$. The go/no-go task measures response inhibition, and is associated with activation of medial prefrontal, dorsolateral prefrontal, and parietal areas [111]. Response activation is diminished in PTSD and other anxiety disorders, and increased activation predicts response to treatment [112]. CBD produced no changes in predicted areas (relative to placebo) but reduced activation in the left insula, superior temporal gyrus, and transverse temporal gyrus. The fearful faces task activates the amygdala, and other medial temporal areas involved in 
Table 2 Human psychological studies

\begin{tabular}{|c|c|c|c|c|}
\hline Study & $\begin{array}{l}\text { Subjects, } \\
\text { design }\end{array}$ & $\begin{array}{l}\text { CBD route, } \\
\text { dose }\end{array}$ & Measure & Effect \\
\hline Karniol et al. [99] & $\begin{array}{l}\mathrm{HV} \\
\mathrm{DBP}\end{array}$ & $\begin{array}{l}\text { Oral, } 15,30,60 \mathrm{mg} \text {, alone } \\
\text { or with THC, } \\
\text { acute, at } 55,95,155 \text {, and } \\
185 \mathrm{~min}\end{array}$ & $\begin{array}{l}\text { Anxiety and pulse rate after } \\
\text { THC and at baseline }\end{array}$ & $\begin{array}{l}\downarrow \text { THC-induced increases in } \\
\text { subjective anxiety and } \\
\text { pulse rate } \\
\text { No effect at } \\
\text { baseline }\end{array}$ \\
\hline Zuardi et al., [100] & $\begin{array}{l}\text { HV, } \\
\text { DBP }\end{array}$ & $\begin{array}{l}\text { Oral } 1 \mathrm{mg} / \mathrm{kg} \text { alone or with } \\
\text { THC, acute, } 80 \mathrm{~min}\end{array}$ & STAI score after THC & $\begin{array}{l}\downarrow \text { THC-induced increases in } \\
\text { STAI scores }\end{array}$ \\
\hline Zuardi et al. [98] & $\begin{array}{l}\mathrm{HV} \\
\mathrm{DBP}\end{array}$ & $\begin{array}{l}\text { Oral } 300 \mathrm{mg} \text {, } \\
\text { acute, } 80 \mathrm{~min}\end{array}$ & $\begin{array}{l}\text { VAMS, STAI and BP } \\
\text { following SPST }\end{array}$ & $\begin{array}{l}\downarrow \text { STAI scores } \\
\downarrow \text { VAMS scores } \\
\downarrow \text { BP }\end{array}$ \\
\hline Martin-Santos et al. [101] & $\begin{array}{l}\text { HV, } \\
\text { DBP }\end{array}$ & $\begin{array}{l}\text { Oral } 600 \mathrm{mg} \text {, } \\
\text { acute, } 1,2,3 \mathrm{~h}\end{array}$ & $\begin{array}{l}\text { Baseline anxiety and } \\
\text { pulse rate }\end{array}$ & No effect \\
\hline Crippa et al. [102] & $\begin{array}{l}10 \mathrm{HV} \\
\mathrm{DBP}\end{array}$ & $\begin{array}{l}\text { Oral } 400 \mathrm{mg} \text {, } \\
\text { acute, } 60 \text { and } 75 \mathrm{~min}\end{array}$ & $\begin{array}{l}\text { VAMS before SPECT } \\
\text { SPECT }\end{array}$ & $\downarrow$ VAMS scores \\
\hline Bhattacharyya et al. [103] & $\begin{array}{l}15 \mathrm{HV} \\
\text { DBP }\end{array}$ & $\begin{array}{l}\text { Oral } 600 \mathrm{mg} \text {, } \\
\text { acute, } 1,2,3 \mathrm{~h}\end{array}$ & $\begin{array}{l}\text { STAI scores } \\
\text { VAMS scores }\end{array}$ & $\begin{array}{l}\downarrow \text { STAI scores } \\
\downarrow \text { VAMS scores }\end{array}$ \\
\hline Crippa et al. [104] & $\begin{array}{l}\text { SAD and } \mathrm{HC} \\
\text { DBP }\end{array}$ & $\begin{array}{l}\text { Oral } 400 \mathrm{mg} \text {, } \\
\text { acute, } 75 \text { and } 140 \mathrm{~min}\end{array}$ & $\begin{array}{l}\text { VAMS before SPECT } \\
\text { SPECT }\end{array}$ & $\downarrow$ VAMS scores \\
\hline Bergamaschi et al. [105] & SAD and HC DBP & $\begin{array}{l}\text { Oral } 600 \mathrm{mg} \text {, acute, } \\
1,2,3 \mathrm{~h}\end{array}$ & $\begin{array}{l}\text { VAMS, SSPS-N, cognitive } \\
\text { impairment, SCR, HR } \\
\text { after SPST }\end{array}$ & $\begin{array}{l}\downarrow \text { VAMS, SSPS-N and cognitive } \\
\text { impairment, no effect on SCR } \\
\text { or HR }\end{array}$ \\
\hline Das et al. [106] & $\begin{array}{l}\mathrm{HV} \\
\mathrm{DBP}\end{array}$ & $\begin{array}{l}\text { Inhaled, } 32 \mathrm{mg} \text {, acute, } \\
\text { immediately following, } \\
\text { before, after extinction }\end{array}$ & $\begin{array}{l}\text { SCR and shock expectancy } \\
\text { following extinction }\end{array}$ & $\begin{array}{l}\text { CBD after extinction training } \\
\text { produced trend level reduction } \\
\text { in SCR and decreased shock } \\
\text { expectancy }\end{array}$ \\
\hline Hindocha et al. [107] & $\begin{array}{l}\text { Varying in schizotypy and } \\
\text { cannabis use, DBP }\end{array}$ & Inhaled, $16 \mathrm{mg}$, acute & Baseline VAS anxiety & No significant effect of CBD \\
\hline
\end{tabular}

$\mathrm{HV}=$ healthy volunteers; $\mathrm{DBP}=$ double-blind placebo; $\mathrm{SAD}=$ social anxiety disorder; $\mathrm{HC}=$ healthy controls; $\mathrm{THC}={ }^{\Delta}$ 9-tetrahydrocannabinol; $\mathrm{STAI}=$ Spielberger's state trait anxiety inventory; VAMS = visual analog mood scale; BP = blood pressure; SPST = simulated public speaking test; SCR = skin conductance response; $\mathrm{SPECT}$ = single-photon emission computed tomography; SSPS-N = negative self-evaluation subscale; HR = heart rate; VAS = visual analog scale, $\mathrm{CBD}=$ cannabidiol

Table 3 Neuroimaging studies

\begin{tabular}{|c|c|c|c|c|}
\hline Study & Subjects, design & CBD route, dose, timing & Measure & Effect of CBD \\
\hline Crippa et al. [102] & $\begin{array}{l}10 \mathrm{HV} \\
\text { DBP }\end{array}$ & $\begin{array}{l}\text { Oral } 400 \mathrm{mg} \text {, } \\
\text { acute, } 60 \text { and } 75 \mathrm{~min}\end{array}$ & SPECT, resting (rCBF) & $\begin{array}{l}\downarrow \mathrm{rCBF} \text { in left medial temporal cluster, } \\
\text { including amygdala and HPC, also } \downarrow \text { rCBF } \\
\text { in the HYP and posterior cingulate gyrus } \\
\uparrow \mathrm{rCBF} \text { in left PHG }\end{array}$ \\
\hline Borgwardt et al. [108] & $\begin{array}{l}15 \mathrm{HV} \\
\text { DBP }\end{array}$ & $\begin{array}{l}\text { Oral } 600 \mathrm{mg} \text {, } \\
\text { acute, } 1-2 \mathrm{~h}\end{array}$ & $\begin{array}{l}\text { fMRI during oddball and } \\
\text { go/no-go task }\end{array}$ & $\downarrow$ Activation in left insula, STG and MTG \\
\hline Fusar-Poli et al. [109] & $\begin{array}{l}15 \mathrm{HV}, \\
\text { DBP }\end{array}$ & $\begin{array}{l}\text { Oral } 600 \mathrm{mg} \text {, } \\
\text { acute, } 1-2 \mathrm{~h}\end{array}$ & $\begin{array}{l}\text { fMRI activation during } \\
\text { fearful faces task }\end{array}$ & $\begin{array}{l}\downarrow \text { Activation in left medial temporal region, } \\
\text { including amygdala and anterior PHG, and } \\
\text { in right ACC and PCC }\end{array}$ \\
\hline Fusar-Poli et al. [110] & $\begin{array}{l}15 \mathrm{HV} \\
\text { DBP }\end{array}$ & $\begin{array}{l}\text { Oral } 600 \mathrm{mg} \text {, } \\
\text { acute, } 1-2 \mathrm{~h}\end{array}$ & $\begin{array}{l}\text { fMRI functional connectivity } \\
\text { during fearful faces task }\end{array}$ & $\begin{array}{l}\downarrow \text { Functional connectivity between L) AMY } \\
\text { and ACC }\end{array}$ \\
\hline Crippa et al. [104] & $\begin{array}{l}\mathrm{SAD} \text { and } \mathrm{HC} \\
\mathrm{DBP}\end{array}$ & $\begin{array}{l}\text { Oral } 400 \mathrm{mg} \text {, } \\
\text { acute, } 75 \text { and } 140 \mathrm{~min}\end{array}$ & SPECT, resting (rCBF) & $\begin{array}{l}\downarrow \mathrm{rCBF} \text { in the left PHG, HPC and ITG. } \\
\uparrow \mathrm{rCBF} \text { in the right posterior cingulate gyrus }\end{array}$ \\
\hline
\end{tabular}

$\mathrm{CBD}=$ cannabidiol; $\mathrm{HV}=$ healthy controls; $\mathrm{DBP}=$ double-blind placebo; $\mathrm{SAD}=$ social anxiety disorder; $\mathrm{HC}=$ healthy controls; $\mathrm{SPECT}=$ single-photo emission computed tomography; $\mathrm{rCBF}=$ regional cerebral blood flow; $\mathrm{fMRI}=$ functional magnetic resonance imaging; $\mathrm{HPC}=$ hippocampus; $\mathrm{HYP}=$ hypothalamus; $\mathrm{PHG}=$ parahippocampal gyrus; $\mathrm{STG}=$ superior temporal gyrus; $\mathrm{MTG}=$ medial temporal gyrus; $\mathrm{ACC}=$ anterior cingulate cortex; $\mathrm{PCC}=$ posterior cingulate cortex 
emotion processing, and heightened amygdala response activation has been reported in anxiety disorders, including GAD and PTSD $[113,114]$. CBD attenuated blood-oxygen-level dependent activation in the left amygdala, and the anterior and posterior cingulate cortex in response to intensely fearful faces, and also reduced amplitude in skin conductance fluctuation, which was highly correlated with amygdala activation [109]. Dynamic causal modeling analysis in this data set further showed CBD reduced forward functional connectivity between the amygdala and anterior cingulate cortex [110].

\section{Evidence from Epidemiological and Chronic Studies}

Epidemiological studies of various neuropsychiatric disorders indicate that a higher CBD content in chronically consumed cannabis may protect against adverse effects of THC, including psychotic symptoms, drug cravings, memory loss, and hippocampal gray matter loss [115-118] (reviewed in [119]). As THC acutely induces anxiety, this pattern may also be evident for chronic anxiety symptoms. Two studies were identified, including an uncontrolled retrospective study in civilian patients with PTSD patients [120], and a case study in a patient with severe sexual abuse-related PTSD [121], which showed that chronic cannabis use significantly reduces PTSD symptoms; however, these studies did not include data on the THC:CBD ratio. Thus, overall, no outcome data are currently available regarding the chronic effects of CBD in the treatment of anxiety symptoms, nor do any data exist regarding the potential protective effects of CBD on anxiety potentially induced by chronic THC use.

\section{Summary and Clinical Relevance}

Evidence from human studies strongly supports the potential for CBD as a treatment for anxiety disorders: at oral doses ranging from 300 to $600 \mathrm{mg}$, CBD reduces experimentally induced anxiety in healthy controls, without affecting baseline anxiety levels, and reduces anxiety in patients with SAD. Limited results in healthy subjects also support the efficacy of CBD in acutely enhancing fear extinction, suggesting potential for the treatment of PTSD, or for enhancing cognitive behavioral therapy. Neuroimaging findings provide evidence of neurobiological targets that may underlie CBD's anxiolytic effects, including reduced amygdala activation and altered medial prefrontal amygdala connectivity, although current findings are limited by small sample sizes, and a lack of independent replication. Further studies are also required to establish whether chronic, in addition to acute CBD dosing is anxiolytic in human. Also, clinical findings are currently limited to $\mathrm{SAD}$, whereas preclinical evidence suggests CBD's potential to treat multiple symptom domains relevant to GAD, $\mathrm{PD}$, and, particularly, PTSD.

\section{Conclusions}

Preclinical evidence conclusively demonstrates CBD's efficacy in reducing anxiety behaviors relevant to multiple disorders, including PTSD, GAD, PD, OCD, and SAD, with a notable lack of anxiogenic effects. CBD's anxiolytic actions appear to depend upon $\mathrm{CB}_{1} \mathrm{Rs}$ and $5-\mathrm{HT}_{1 \mathrm{~A}} \mathrm{Rs}$ in several brain regions; however, investigation of additional receptor actions may reveal further mechanisms. Human experimental findings support preclinical findings, and also suggest a lack of anxiogenic effects, minimal sedative effects, and an excellent safety profile. Current preclinical and human findings mostly involve acute CBD dosing in healthy subjects, so further studies are required to establish whether chronic dosing of CBD has similar effects in relevant clinical populations. Overall, this review emphasizes the potential value and need for further study of CBD in the treatment of anxiety disorders.

Required Author Forms Disclosure forms provided by the authors are available with the online version of this article.

\section{References}

1. Kroenke K, Spitzer RL, Williams JB, Monahan PO, Lowe B. Anxiety disorders in primary care: prevalence, impairment, comorbidity, and detection. Ann Intern Med 2007;146:317-325.

2. Khan A, Leventhal RM, Khan S, Brown WA. Suicide risk in patients with anxiety disorders: a meta-analysis of the FDA database. J Affect Disord 2002;68:183-190.

3. Olatunji BO, Cisler JM, Tolin DF. Quality of life in the anxiety disorders: a meta-analytic review. Clin Psychol Rev 2007;27:572-581.

4. Kessler RC, Berglund P, Demler O, Jin R, Merikangas KR, Walters EE. Lifetime prevalence and age-of-onset distributions of DSM-IV disorders in the National Comorbidity Survey Replication. Arch Gen Psychiatry 2005;62:593-602.

5. Wang PS, Lane M, Olfson M, Pincus HA, Wells KB, Kessler RC. Twelve-month use of mental health services in the United States: results from the National Comorbidity Survey Replication. Arch Gen Psychiatry 2005;62:629-640.

6. Gustavsson A, Svensson M, Jacobi F, et al. Cost of disorders of the brain in Europe 2010. Eur Neuropsychopharmacol 2011;21:718-779.

7. Otto MW, Tuby KS, Gould RA, McLean RY, Pollack MH. An effect-size analysis of the relative efficacy and tolerability of serotonin selective reuptake inhibitors for panic disorder. Am J Psychiary 2001;158:1989-1992.

8. Ballenger JC. Remission rates in patients with anxiety disorders treated with paroxetine. J Clin Psychiatry 2004;65:1696-1707.

9. Krystal JH, Rosenheck RA, Cramer JA, et al. Adjunctive risperidone treatment for antidepressant-resistant symptoms of chronic military service-related PTSD: a randomized trial. JAMA 2011;306:493-502.

10. Shin HJ, Greenbaum MA, Jain S, Rosen CS. Associations of psychotherapy dose and SSRI or SNRI refills with mental health outcomes among veterans with PTSD. Psychiatr Serv 2014;65: 1244-1248.

11. Izzo AA, Borrelli F, Capasso R, Di Marzo V, Mechoulam R. Nonpsychotropic plant cannabinoids: new therapeutic opportunities from an ancient herb. Trends Pharmacol Sci 2009;30:515-527. 
12. Campos AC, Moreira FA, Gomes FV, Del Bel EA, Guimaraes FS. Multiple mechanisms involved in the large-spectrum therapeutic potential of cannabidiol in psychiatric disorders. Philos Trans R Soc Lond Ser B Biol Sci 2012;367:3364-3378.

13. Schier ARD, Ribeiro NP, Silva AC, et al. Cannabidiol, a Cannabis sativa constituent, as an anxiolytic drug. Rev Bras Psiquiatr 2012;34:S104-S117.

14. Schier ARD, de Oliveira Ribeiro NP, Coutinho DS, et al. Antidepressant-like and anxiolytic-like effects of cannabidiol: A chemical compound of Cannabis sativa. CNS Neurol Disord Drug Targets 2014;13:953-960.

15. Micale V, Di Marzo V, Sulcova A, Wotjak CT, Drago F. Endocannabinoid system and mood disorders: priming a target for new therapies. Pharmacol Ther 2013;138:18-37.

16. Mechoulam R, Peters M, Murillo-Rodriguez E, Hanus LO. Cannabidiol—recent advances. Chem Biodivers 2007;4:16781692.

17. Marco EM, Garcia-Gutierrez MS, Bermudez-Silva FJ, et al. Endocannabinoid system and psychiatry: in search of a neurobiological basis for detrimental and potential therapeutic effects. Front Behav Neurosci 2011;5:63.

18. Devinsky O, Cilio MR, Cross H, et al. Cannabidiol: Pharmacology and potential therapeutic role in epilepsy and other neuropsychiatric disorders. Epilepsia 2014;55:791-802.

19. Robson PJ, Guy GW, Di Marzo V. Cannabinoids and schizophrenia: therapeutic prospects. Curr Pharm Design 2014;20:2194-2204.

20. Bergamaschi MM, Queiroz RH, Zuardi AW, Crippa JA. Safety and side effects of cannabidiol, a Cannabis sativa constituent. Curr Drug Saf 2011;6: 237-249.

21. McPartland JM, Duncan M, Di Marzo V, Pertwee RG. Are cannabidiol and Delta(9) -tetrahydrocannabivarin negative modulators of the endocannabinoid system? A systematic review. Br J Pharmacol 2015;172:737-753.

22. Di Marzo V, Bisogno T, De Petrocellis L. Anandamide: Some like it hot. Trends Pharmacol Sci 2001;22:346-349.

23. Wilson RI, Nicoll RA. Endocannabinoid signaling in the brain. Science 2002;296: 678-682.

24. Battista N, Di Tommaso M, Bari M, Maccarrone M. The endocannabinoid system: An overview. Front Behav Neurosci 2012;6:9

25. Lee $\mathrm{SH}$, et al. Multiple forms of endocannabinoid and endovanilloid signaling regulate the tonic control of GABA release. J Neurosci 2015;35:10039-10057.

26. Kauer JA, Gibson HE. Hot flash: TRPV channels in the brain. Trends Neurosci 2009;32:215-224.

27. Aguiar DC, Moreira FA, Terzian AL, et al. Modulation of defensive behavior by transient receptor potential vanilloid type-1 (TRPV1) channels. Neurosci Biobehav Rev 2014;46:418-428.

28. Silvestri C, Di Marzo V. The endocannabinoid system in energy homeostasis and the etiopathology of metabolic disorders. Cell Metab 2013;17:475-490.

29. Castillo PE, Younts TJ, Chavez AE, Hashimotodani Y. Endocannabinoid signaling and synaptic function. Neuron 2012;76:70-81.

30. Riebe CJ, Pamplona FA, Kamprath K, Wotjak CT. Fear relieftoward a new conceptual frame work and what endocannabinoids gotta do with it. Neuroscience 2012;204:159-185.

31. McLaughlin RJ, Hill MN, Gorzalka BB. A critical role for prefrontocortical endocannabinoid signaling in the regulation of stress and emotional behavior. Neurosci Biobehav Rev 2014;42: 116-131.

32. Moreira FA, Lutz B. The endocannabinoid system: emotion, learning and addiction. Addict Biol 2008;13:196-212.

33. Ruehle S, Rey AA, Remmers F, Lutz B. The endocannabinoid system in anxiety, fear memory and habituation. J Psychopharmacol 2012;26:23-39.
34. Llorente-Berzal A, Terzian AL, di Marzo V, Micale V, Viveros MP, Wotjak CT. 2-AG promotes the expression of conditioned fear via cannabinoid receptor type 1 on GABAergic neurons. Psychopharmacology 2015;232: 2811-2825.

35. Marsicano G, Wotjak CT, Azad SC, et al. The endogenous cannabinoid system controls extinction of aversive memories. Nature 2002;418:530-534.

36. Dincheva I, Drysdale AT, Hartley CA. FAAH genetic variation enhances fronto-amygdala function in mouse and human. Nat Commun 2015;6:6395.

37. Gray JM, Vecchiarelli HA, Morena M, et al. Corticotropinreleasing hormone drives anandamide hydrolysis in the amygdala to promote anxiety. J Neurosci 2015;35:3879-3892.

38. Evanson NK, Tasker JG, Hill MN, Hillard CJ, Herman JP. Fast feedback inhibition of the HPA axis by glucocorticoids is mediated by endocannabinoid signaling. Endocrinology 2010;151:4811-4819.

39. Abush H, Akirav I. Cannabinoids ameliorate impairments induced by chronic stress to synaptic plasticity and short-term memory. Neuropsychopharmacology 2013;38:1521-1534.

40. Hill MN, Patel S, Carrier EJ, et al. Downregulation of endocannabinoid signaling in the hippocampus following chronic unpredictable stress. Neuropsychopharmacology 2005;30;508-515.

41. Qin Z, Zhou X, Pandey NR, et al. Chronic stress induces anxiety via an amygdalar intracellular cascade that impairs endocannabinoid signaling. Neuron 2015;85:1319-1331.

42. Neumeister A. The endocannabinoid system provides an avenue for evidence-based treatment development for PTSD. Depress Anxiety 2013;30:93-96.

43. Papini S, Sullivan GM, Hien DA, Shvil E, Neria Y. Toward a translational approach to targeting the endocannabinoid system in posttraumatic stress disorder: a critical review of preclinical research. Biol Psychol 2015;104:8-18.

44. Ragen BJ, Seidel J, Chollak C, Pietrzak RH, Neumeister A. Investigational drugs under development for the treatment of PTSD. Exp Opin Invest Drugs 2015;24:659-672.

45. Viveros MP, Marco EM, File SE. Endocannabinoid system and stress and anxiety responses. Pharmacol Biochem Behav 2005;81:331-342.

46. Rubino T, Realini N, Castiglioni C, et al. Role in anxiety behavior of the endocannabinoid system in the prefrontal cortex. Cereb Cortex 2008;18:1292-1301.

47. Moreira FA, Aguiar DC, Terzian AL, Guimaraes FS, Wotjak CT. Cannabinoid type 1 receptors and transient receptor potential vanilloid type 1 channels in fear and anxiety-two sides of one coin? Neuroscience 2012;204:186-192.

48. Bisogno T, Hanus L, De Petrocellis L, et al. Molecular targets for cannabidiol and its synthetic analogues: effect on vanilloid VR1 receptors and on the cellular uptake and enzymatic hydrolysis of anandamide. Br J Pharmacol 2001;134:845-852.

49. Haller $\mathrm{J}$, et al. Interactions between environmental aversiveness and the anxiolytic effects of enhanced cannabinoid signaling by FAAH inhibition in rats. Psychopharmacology 2009;204:607-616.

50. Chessick CA, Allen MH, Thase M, et al. Azapirones for generalized anxiety disorder. Cochrane Database Syst Rev 2006; CD006115.

51. Roncon CM, Biesdorf C, Coimbra NC, et al. Cooperative regulation of anxiety and panic-related defensive behaviors in the rat periaqueductal grey matter by 5 -HT1A and mu-receptors. J Psychopharmacol 2013;27:1141-1148.

52. Zhou J, Cao X, Mar AC, et al. Activation of postsynaptic 5-HT1A receptors improve stress adaptation. Psychopharmacology 2014;231:2067-2075.

53. Saito Y, Matsumoto M, Yanagawa $Y$, et al. Facilitation of fear extinction by the 5-HT(1A) receptor agonist tandospirone: possible involvement of dopaminergic modulation. Synapse 2013;67:161-170. 
54. Sprouse JS, Aghajanian GK. Electrophysiological responses of serotoninergic dorsal raphe neurons to 5-HT1A and 5-HT1B agonists. Synapse 1987;1:3-9.

55. Sun YN, Wang T, Wang Y, et al. Activation of 5-HT receptors in the medial subdivision of the central nucleus of the amygdala produces anxiolytic effects in a rat model of Parkinson's disease. Neuropharmacology 2015;95:181-191.

56. Celada P, Bortolozzi A, Artigas F. Serotonin 5-HT1A receptors as targets for agents to treat psychiatric disorders: rationale and current status of research. CNS Drugs 2013;27:703-716.

57. Russo EB, Burnett A, Hall B, Parker KK. Agonistic properties of cannabidiol at 5-HT1a receptors. Neurochem Res 2005;30:10371043.

58. Rock EM, Bolognini D, Limebeer CL, et al. Cannabidiol, a nonpsychotropic component of cannabis, attenuates vomiting and nausea-like behaviour via indirect agonism of 5-HT(1A) somatodendritic autoreceptors in the dorsal raphe nucleus. Br J Pharmacol 2012;165:2620-2634.

59. Silveira Filho NG, Tufik S. Comparative effects between cannabidiol and diazepam on neophobia, food intake and conflict behavior. Res Commun Psychol Psychiatry Behav 1981;6:25-26.

60. Zuardi AW, Finkelfarb E, Bueno OF, Musty RE, Karniol IG. Characteristics of the stimulus produced by the mixture of cannabidiol with delta 9-tetrahydrocannabinol. Arch Int Pharmacodyn Ther 1981;249:137-146.

61. Onaivi ES, Green MR, Martin BR. Pharmacological characterization of cannabinoids in the elevated plus maze. J Pharmacol Exp Ther 1990;253:1002-1009.

62. Moreira FA, Aguiar DC, Guimaraes FS. Anxiolytic-like effect of cannabidiol in the rat Vogel conflict test. Prog Neuropsychopharmacol Biol Psychiatry 2006;30:1466-1471.

63. Resstel LB, Joca SR, Moreira FA, Correa FM, Guimaraes FS. Effects of cannabidiol and diazepam on behavioral and cardiovascular responses induced by contextual conditioned fear in rats. Behav Brain Res 2006;172:294-298.

64. Campos AC, Guimaraes FS. Involvement of 5HT1A receptors in the anxiolytic-like effects of cannabidiol injected into the dorsolateral periaqueductal gray of rats. Psychopharmacology (Berl) 2008;199:223-230.

65. Bitencourt RM, Pamplona FA, Takahashi RN. Facilitation of contextual fear memory extinction and anti-anxiogenic effects of AM40 4 and cannabidiol in conditioned rats. Eur Neuropsychopharmacol 2009;18:849-859.

66. Campos AC, Guimaraes FS. Evidence for a potential role for TRPV1 receptors in the dorsolateral periaqueductal gray in the attenuation of the anxiolytic effects of cannabinoids. Prog Neuropsychopharmacol Biol Psychiatry 2009;33:1517-1521.

67. Resstel LB, Tavares RF, Lisboa SF, et al. 5-HT1A receptors are involved in the cannabidiol-induced attenuation of behavioural and cardiovascular responses to acute restraint stress in rats. Br J Pharmacol 2009;156:181-188.

68. Soares Vde P, Campos AC, Bortoli VC, et al. Intra-dorsal periaqueductal gray administration of cannabidiol blocks paniclike response by activating 5-HT1A receptors. Behav Brain Res 2010;213:225-229.

69. Long LE, Chesworth R, Huang XF. A behavioural comparison of acute and chronic Delta9-tetrahydrocannabinol and cannabidiol in C57BL/6JArc mice. Int J Neuropsychopharmacol 2010;13:861-876.

70. Lemos JI, Resstel LB, Guimaraes FS. Involvement of the prelimbic prefrontal cortex on cannabidiol-induced attenuation of contextual conditioned fear in rats. Behav Brain Res 2010;207:105-111.

71. Casarotto PC, Gomes FV, Resstel LB, Guimaraes FS. Cannabidiol inhibitory effect on marble-burying behaviour: involvement of CB1 receptors. Behav Pharmacol 2010;21:353-358.
72. Gomes FV, Resstel LB, Guimaraes FS. The anxiolytic-like effects of cannabidiol injected into the bed nucleus of the stria terminalis are mediated by 5 -HT1A receptors. Psychopharmacology (Berl) 2011;213:465-473.

73. Granjeiro EM, Gomes FV, Guimaraes FS, Correa FM, Resstel LB. Effects of intracisternal administration of cannabidiol on the cardiovascular and behavioral responses to acute restraint stress. Pharmacol Biochem Behav 2011;99:743-748.

74. Deiana S, Watanabe A, Yamasaki Y. Plasma and brain pharmacokinetic profile of cannabidiol (CBD), cannabidivarine (CBDV), Delta(9)-tetrahydrocannabivarin (THCV) and cannabigerol (CBG) in rats and mice following oral and intraperitoneal administration and CBD action on obsessive-compulsive behaviour. Psychopharmacology (Berl) 2012;219:859-873.

75. Uribe-Marino A, et al. Anti-aversive effects of cannabidiol on innate fear-induced behaviors evoked by an ethological model of panic attacks based on a prey vs the wild snake Epicrates cenchria crassus confrontation paradigm. Neuropsychopharmacology 2012;37:412-421.

76. Stern CA, Gazarini L, Takahashi RN, Guimaraes FS, Bertoglio LJ. On disruption of fear memory by reconsolidation blockade: evidence from cannabidiol treatment. Neuropsychopharmacology 2012;37:2132-2142.

77. Campos AC, Ferreira FR, Guimaraes FS. Cannabidiol blocks long-lasting behavioral consequences of predator threat stress: possible involvement of 5HT1A receptors. J Psychiatr Res 2012;46:1501-1510.

78. Hsiao YT, Yi PL, Li CL, Chang FC. Effect of cannabidiol on sleep disruption induced by the repeated combination tests consisting of open field and elevated plus-maze in rats. Neuropharmacology 2012;62:373-384.

79. Gomes FV, Resstel LB, Guimaraes FS, et al. Cannabidiol injected into the bed nucleus of the stria terminalis reduces the expression of contextual fear conditioning via 5-HT1A receptors. J Psychopharmacol 2012;26:104-113.

80. El Batsh MM, Assareh N, Marsden CA, Kendall DA. Anxiogeniclike effects of chronic cannabidiol administration in rats. Psychopharmacology (Berl) 2012;221:239-247.

81. Campos AC, Ortega Z, Palazuelos J, et al. The anxiolytic effect of cannabidiol on chronically stressed mice depends on hippocampal neurogenesis: involvement of the endocannabinoid system. Int J Neuropsychopharmacol 2013;16:1407-1419.

82. Do Monte FH, Souza RR, Bitencourt RM, Kroon JA, Takahashi $\mathrm{RN}$. Infusion of cannabidiol into infralimbic cortex facilitates fear extinction via CB1 receptors. Behav Brain Res 2013;250:23-27.

83. Campos AC, de Paula Soares V, Carvalho MC, et al. Involvement of serotonin-mediated neurotransmission in the dorsal periaqueductal gray matter on cannabidiol chronic effects in panic-like responses in rats. Psychopharmacology (Berl) 2013;226:13-24.

84. Almeida V, Levin R, Peres FF, et al. Cannabidiol exhibits anxiolytic but not antipsychotic property evaluated in the social interaction test. Prog Neuropsychopharmacol Biol Psychiatry 2013;41: 30-35.

85. Gomes FV, Alves FH, Guimaraes FS, et al. Cannabidiol administration into the bed nucleus of the stria terminalis alters cardiovascular responses induced by acute restraint stress through 5-HT(1)A receptor. Eur Neuropsychopharmacol 2013;23:1096-1104.

86. Twardowschy A, Castiblanco-Urbina MA, Uribe-Marino A, et al. The role of 5-HT1A receptors in the anti-aversive effects of cannabidiol on panic attack-like behaviors evoked in the presence of the wild snake Epicrates cenchria crassus (Reptilia, Boidae). J Psychopharmacol 2013;27:1149-1159.

87. Fogaca MV, Reis FM, Campos AC, Guimaraes FS. Effects of intra-prelimbic prefrontal cortex injection of cannabidiol on anxiety-like behavior: involvement of 5HT1A receptors and 
previous stressful experience. Eur Neuropsychopharmacol 2014;24:410-419.

88. Nardo M, Casarotto PC, Gomes FV, Guimaraes FS. Cannabidiol reverses the $\mathrm{mCPP}$-induced increase in marble-burying behavior. Fundam Clin Pharmacol 2014;28:544-550.

89. da Silva JA, Biagioni AF, Almada RC, et al. Dissociation between the panicolytic effect of cannabidiol microinjected into the substantia nigra, pars reticulata, and fear-induced antinociception elicited by bicuculline administration in deep layers of the superior colliculus: The role of CB-cannabinoid receptor in the ventral mesencephalon. Eur J Pharmacol 2015;758:153-163.

90. Guimaraes FS, Chiaretti TM, Graeff FG, Zuardi AW. Antianxiety effect of cannabidiol in the elevated plus-maze. Psychopharmacology (Berl) 1990;100:558-559.

91. Bandler R, Shipley MT. Columnar organization in the midbrain periaqueductal gray: modules for emotional expression? Trends Neurosci 1994;17:379-389.

92. Nashold BS, Jr, Wilson WP, Slaughter DG. Sensations evoked by stimulation in the midbrain of man. J Neurosurg 1969;30:14-24.

93. Walker DL, Miles LA, Davis M. Selective participation of the bed nucleus of the stria terminalis and CRF in sustained anxiety-like versus phasic fear-like responses. Prog Neuropsychopharmacol Biol Psychiatry 2009;33:1291-1308.

94. Sierra-Mercado D, Padilla-Coreano N, Quirk GJ. Dissociable roles of prelimbic and infralimbic cortices, ventral hippocampus, and basolateral amygdala in the expression and extinction of conditioned fear. Neuropsychopharmacology 2011;36:529-538.

95. Schenberg LC, Bittencourt AS, Sudre EC, Vargas LC. Modeling panic attacks. Neurosci Biobehav Rev 2001;25;647-659.

96. Thomas A, Burant A, Bui N, Graham D, Yuva-Paylor LA, Paylor R. Marble burying reflects a repetitive and perseverative behavior more than novelty-induced anxiety. Psychopharmacology (Berl) 2009;204;361-373.

97. Suzuki A, Josselyn SA, Frankland PW, et al. Memory reconsolidation and extinction have distinct temporal and biochemical signatures. J Neurosci 2004;24:4787-4795.

98. Zuardi AW, Shirakawa I, Finkelfarb E, Karniol IG. Action of cannabidiol on the anxiety and other effects produced by delta 9-THC in normal subjects. Psychopharmacology (Berl) 1982;76: 245-250.

99. Karniol IG, Shirakawa I, Kasinski N, Pfeferman A, Carlini EA. Cannabidiol interferes with the effects of delta 9 - tetrahydrocannabinol in man. Eur J Pharmacol 1974;28:172-177.

100. Zuardi AW, Cosme RA, Graeff FG, Guimaraes FS. Effects of ipsapirone and cannabidiol on human experimental anxiety. J Psychopharmacol 1993;7:82-88.

101. Martin-Santos R, Crippa JA, Batalla A, et al. Acute effects of a single, oral dose of d9-tetrahydrocannabinol (THC) and cannabidiol (CBD) administration in healthy volunteers. Curr Pharm Design 2012;18:4966-4979.

102. Crippa JA, Zuardi AW, Garrido GE, et al. Effects of cannabidiol (CBD) on regional cerebral blood flow. Neuropsychopharmacology 2004;29:417-426.

103. Bhattacharyya S, Morrison PD, Fusar-Poli P, et al. Opposite effects of delta-9-tetrahydrocannabinol and cannabidiol on human brain function and psychopathology. Neuropsychopharmacology 2010;35:764-774.

104. Crippa JA, Derenusson GN, Ferrari TB, et al. Neural basis of anxiolytic effects of cannabidiol (CBD) in generalized social anxiety disorder: a preliminary report. J Psychopharmacol 2011;25: 121-130.
105. Bergamaschi MM, Queiroz RH, Chagas MH, et al. Cannabidiol reduces the anxiety induced by simulated public speaking in treatment-naive social phobia patients. Neuropsychopharmacology 2011;36:1219-1226.

106. Das RK, Kamboj SK, Ramadas M, et al. Cannabidiol enhances consolidation of explicit fear extinction in humans. Psychopharmacology 2013;226:781-792.

107. Hindocha C, Freeman TP, Schafer G, et al. Acute effects of delta9-tetrahydrocannabinol, cannabidiol and their combination on facial emotion recognition: a randomised, double-blind, placebocontrolled study in cannabis users. Eur Neuropsychopharmacol 2015;25:325-334.

108. Borgwardt SJ, Allen P, Bhattacharyya S, et al. Neural basis of Delta-9-tetrahydrocannabinol and cannabidiol: effects during response inhibition. Biol Psychiatry 2008;64:966-973.

109. Fusar-Poli P, Crippa JA, Bhattacharyya S. Distinct effects of \{delta\}9-tetrahydrocannabinol and cannabidiol on neural activation during emotional processing. Arch Gen Psychiatry 2009;66:95105.

110. Fusar-Poli P, Allen P, Bhattacharyya S. Modulation of effective connectivity during emotional processing by Delta 9 tetrahydrocannabinol and cannabidiol. Int J Neuropsychopharmacol 2010;13:421-432.

111. Rubia K, Russell T, Overmeyer S, et al. Mapping motor inhibition: conjunctive brain activations across different versions of go/no-go and stop tasks. Neuroimage 2001;13:250-261.

112. Falconer E, Allen A, Felmingham KL, Williams LM, Bryant RA. Inhibitory neural activity predicts response to cognitive-behavioral therapy for posttraumatic stress disorder. J Clin Psychiatry 2013;74:895-901.

113. Mochcovitch MD, da Rocha Freire RC, Garcia RF, Nardi AE. A systematic review of fMRI studies in generalized anxiety disorder: evaluating its neural and cognitive basis. J Affect Disord 2014; 167:336-342.

114. Patel R, Spreng RN, Shin LM, Girard TA. Neurocircuitry models of posttraumatic stress disorder and beyond: a meta-analysis of functional neuroimaging studies. Neurosci Biobehav Rev 2012;36:2130-2142.

115. Morgan CJ, Freeman TP, Schafer GL, Curran HV. Cannabidiol attenuates the appetitive effects of Delta 9-tetrahydrocannabinol in humans smoking their chosen cannabis. Neuropsychopharmacology 2010;35: 1879-1885.

116. Morgan CJ, Curran HV. Effects of cannabidiol on schizophrenialike symptoms in people who use cannabis. Br J Psychiatry 2008;192:306-307.

117. Morgan CJ, Schafer G, Freeman TP, Curran HV. Impact of cannabidiol on the acute memory and psychotomimetic effects of smoked cannabis: naturalistic study: naturalistic study [corrected]. Br J Psychiatry 2010;197:285-290.

118. Demirakca T, Sartorius A, Ende G, et al. Diminished gray matter in the hippocampus of cannabis users: possible protective effects of cannabidiol. Drug Alcohol Depend 2011;114:242-245.

119. Niesink RJ, van Laar MW. Does cannabidiol protect against adverse psychological effects of THC? Front Psychiatry 2013;4:130.

120. Greer GR, Grob CS, Halberstadt AL. PTSD symptom reports of patients evaluated for the New Mexico Medical Cannabis Program. J Psychoactive Drugs 2014;46:73-77.

121. Passie T, Emrich HM, Karst M, Brandt SD, Halpern JH. Mitigation of post-traumatic stress symptoms by Cannabis resin: a review of the clinical and neurobiological evidence. Drug Test Anal 2012;4:649-659. 